Received Date : 01-Aug-2016

Revised Date : 13-Sep-2016

Accepted Date : 17-Sep-2016

Article type : Original Article

\title{
Reducing exposure to pathogens in the horse; A preliminary study into the survival of bacteria on a range of equine bedding types.
}

\section{Running headline; Bacteria and equine bedding}

Kelly Yarnell ${ }^{1}$, Melanie Le Bon ${ }^{1}$, Nicholas Turton ${ }^{2}$, Marina Savova ${ }^{2}$, Abigail McGlennon ${ }^{1}$, Stephen Forsythe ${ }^{2}$

${ }^{1}$ School of Animal, Rural and Environmental Sciences, Brackenhurst Campus, Nottingham Trent University, Southwell, Nottingham, United Kingdom, NG25 0QF. *Kelly.yarnell@ntu.ac.uk

${ }^{2}$ School of Science and Technology, Nottingham Trent University, Clifton Lane, Nottingham, United Kingdom, NG11 8NS

\begin{abstract}
Aims; Compare the rate of growth of four microbial strains that cause disease in the equine, on four commonly used types of bedding. The moisture holding capacity of each bedding type was also tested.
\end{abstract}

Methods and results; Microbial strains included, Streptococcus equi, Streptococcus zooepidemicus, Fusobacterium necrophorum, Dichelobacter nodosus and Dermatophilus congolensis. The bedding types tested were Pinus syvestrus (Scots pine shavings), Pinus nigra (Corsican pine shavings), Picea sitchensis (Sitka spruce shavings), Cannabis sativa (hemp) and chopped wheat straw. A suspension of each microbial strain was spread in triplicate on agar media and incubated in its optimal growth conditions. The viable count (colony forming unit per $\mathrm{ml}$ ) was determined for This article has been accepted for publication and undergone full peer review but has not been through the copyediting, typesetting, pagination and proofreading process, which may lead to differences between this version and the Version of Record. Please cite this article as doi: $10.1111 /$ jam. 13298

This article is protected by copyright. All rights reserved. 
each bacterial strain for the five different bedding types. Pinus syvestrus bedding resulted in significantly less $(p=0.001)$ bacterial growth of all strains tested.

Conclusions;. Factors resulting in the inhibition of bacterial growth include the antibacterial effects reported in the Pinacea family and the physical properties of the bedding substrate. Research is currently focussed on the diagnosis and management of disease. Prevention of disease is also important for matters of biosecurity. Strategies should include the provision of a hygienic environment and the use of specific types of bedding.

Significance and impact of the study; Bedding choice has implications for global equine health and disease prevention as well as potential benefits in other animal species.

\section{Keywords}

Microbial contamination; Antimicrobials; Diseases; Streptococci; Veterinary.

\section{Introduction}

Management and control of disease is an ongoing concern in the equine industry due to its potential economic and welfare implications. One of the key aspects of disease control is decreasing exposure to pathogens which at the most basic level includes the provision of a clean living environment for the horse (Equus caballus). Many disease causing pathogens can be transmitted indirectly through sharing of contaminated fomites (Timoney and Kumar, 2008) which could include horse equipment, clothing or bedding. 
Development of improved diagnostic tests and treatment protocols are contributing to the improved management of disease outbreaks in horses (Waller, 2013). However, it is also important that preventative measures be explored. Domestic horses may spend up to twenty three hours per day standing in their stables (Webster et al. 1987) and the bedding materials within those stables have previously been implicated as being a primary source of pathogenic bacteria (Hogan et al. 1990). Therefore, factors related to equine management need to be evaluated including the provision of a suitable bedding material that offers the most hygienic environment for the horse.

Bedding material has been evaluated for properties such as dust production (Elfman et al. 2009), moisture absorbency (Borhan et al. 2014), impact upon equine behaviour (Werhahn et al. 2010) and airborne contamination with straw bedding having higher levels of microbial contamination compared to paper and wood shavings (Tanner et al. 1997). Water holding capacity is of particular importance, as excess moisture in the form of urine in the horses bed can contribute to foot problems (Kaneps, 2014) and gaseous ammonia formation which is known to have detrimental consequences upon the equine respiratory tract (Clarke, 1987).

Common plant based bedding materials used in horse stables include straw, hemp and wood shavings (Borhan et al. 2014). Horse owners will select their bedding type based on availability, cost and ease of disposal (Wheeler et al. 2002). If the bedding used in horse stables were able to resist equine specific pathogens then this has implications for the prevention and control of disease; yet to date, limited investigation of direct bacterial resistance of the bedding types available to horse owners has been carried out. 
Tanner et al. (1997) found a significant increase in airborne microbial contamination in stalls with straw bedding when compared to stalls with wood shavings and paper based bedding. The authors suggested the latter may be the most acceptable bedding types when considering microbial contamination within a stable.

Wood shavings used in equine bedding are sourced from the Pinacea family and many species within this family have been shown to have anti-bacterial effects including Pinus nigra (Sarac et al. 2014), Pinus sylvestris (Rauha et al. 2000), and Picea sitchensis (Liu et al. 2011). Evidence shows the most consistent antibacterial and antifungal properties are associated with extracts of the Pinus species and these effects may be associated with polyphenols in the wood (Valimaa et al. 2007). However, research is primarily based on food hygiene and therapeutics (Valimaa et al. 2007) involving bacteria such as Escherichia coli and Staphylococcus aureus (Rauha et al. 2000).

The current study investigated the survival of four bacteria that can cause disease in horses on four commonly used equine bedding types.

Equine strangles is caused by the bacterium Streptococcus equi and results in significant welfare and economic cost throughout the world (Waller et al. 2013) with approximately 1000 outbreaks of strangles in the UK alone each year (Ivens et al. 2011). Strangles is currently the most frequently diagnosed infectious disease of horses world-wide, responsible for high morbidity and occasional mortality of infected animals (Waller et al. 2013). The bacterium gains access to the horse through the nose or mouth and transmission of the disease occurs by direct contact with an infected horse or contaminated equipment (Lindahl et al. 2011). 
S. equi is believed to have evolved from an ancestral strain of $S$. equi subspecies zooepidemicus (Webb et al. 2008). S. zooepidemicus strains are highly diverse and can cause disease in a variety of other species including humans (Waller, 2013). S. zooepidemicus is part of the normal commensal population of the upper respiratory tract and reproductive tract in horses, however, S. zooepidemicus is also known as an opportunistic pathogen during period of immune vulnerably or stress (Rasmussen et al. 2013; Velineni et al. 2014). In the equine species, S. zooepidemicus is associated with inflammatory airway disease (Wood et al. 2005), and uterine infections in mares (Smith et al. 2003).

Thrush of the equine hoof is recognised as a bacterial infection which in severe cases may result in permanent lameness (Petrov and Dicks, 2013). The condition is associated with $F$. necrophorum even in the absence of $D$. nodosus. This is different from footrot in cattle and sheep, which is caused by the synergistic action of both types of bacteria (Petrov and Dicks, 2013). The condition is degenerative and is commonly associated with poor foot hygiene and dirty bedding (Kaneps, 2014).

Distal limb dermatitis (mudfever) has been associated with the bacteria $D$. congolensis (Colles et al. 2010) and although it is not found free living in the environment, its zoospores can survive for long periods of time (Pilsworth and Knottenbelt, 2007). The condition results in infection of the epidermis and is believed to be spread by direct contact between animals and through contaminated environments. Mudfever commonly affects the lower limb of horses (Pilsworth and Knottenbelt, 2007) and as such reduction of bacterial spores in bedding that is in contact with the lower limb for prolonged periods would be desirable. 
Due to the potential risks associated with contamination of the horses' environment and pathogen transmission, it is important that equine bedding be objectively assessed for its ability to resist bacterial survival and growth.

The aim of this study was to 1) compare the rate of growth of the four bacteria described, on four commonly used types of equine bedding under controlled laboratory conditions and 2) compare the moisture holding capacity of each bedding type.

\section{Materials and Methods}

\section{Bedding types, bacterial strains and reagents}

The bedding types tested were Pinus syvestrus (Scots pine shavings), Pinus nigra (Corsican pine shavings), Picea sitchensis (Sitka spruce shavings), Cannabis sativa (hemp) and chopped wheat straw. Prior to microbiological testing, all bedding ( $2 \mathrm{~g}$ pooled sample) were placed in a glass beaker covered with aluminum foil and autoclaved at $121^{\circ} \mathrm{C}$ for 15 minutes. Isolates of $E$. coli and $D$. congolensis from Nottingham Trent University's culture collection were retrieved from frozen storage ($80^{\circ} \mathrm{C}$ ). S. equi, S. zooepidemicus and D. nodosus were commercially sourced (LGC Standards and Public Health England). All nutrient agar and broth were purchased from Oxoid Thermo Fisher Scientific (Basingtoke, UK) and Defibrinated Horse Blood was purchased from TCS Biosciences (Buckingham, UK). 


\section{Bacterial count methodology}

Each bacterial strain was streaked from the frozen stock onto appropriate agar media. Microbial strains, media and incubation conditions are listed in Table 1. After incubation, purity of the cultures was assessed through morphological assessment on the plate and Gram stain, and a single fresh colony was used to inoculate the broth culture. The culture was diluted at 1 in 10 in fresh broth overnight and $0.7 \mathrm{ml}$ of the dilution was used to inoculate $2 \mathrm{~g}$ of each bedding type. The inoculation dose was determined for each strain; S. zooepidimicus $7.7 \times 10^{5} \mathrm{cfu}$, S. equi $5.5 \times 10^{5} \mathrm{cfu}, E$. coli $5.2 \times 10^{6} \mathrm{cfu}, D$. nodosus: $1.5 \times 10^{4} \mathrm{cfu}$ and D. congolensis: $1.61 \times 10^{4} \mathrm{cfu}$. Bedding with bacterial inoculant were incubated overnight at room temperature $(D$. nodosus was incubated anaerobically). After incubation, the bedding was mixed with $18 \mathrm{ml}$ of $0.85 \%$ saline and homogenised in a Stomacher 400 (Seward, Worthing, UK) for $1 \mathrm{~min}$ at $265 \mathrm{rpm}$. The suspension was decimally diluted in saline and spread in triplicate on their respective agar media and incubated in their optimal growth conditions. The viable count (colony forming unit per $\mathrm{ml}$ ) was determined for each bacterial strain for the 5 different bedding types.

\section{Bacterial count data analysis}

All data were logarithmically (log10) transformed prior to statistical analysis and are expressed as mean value and standard error of three replicate per bedding. All log transformed data were normally distributed and one-way ANOVA was used to compare bacterial count between the bedding 
types. The Tukey post-hoc test was used to determine pairwise significance between groups. Data analysis was performed using IBM SPSS v23 software and Differences were considered significant at $p \leq 0.05$.

\section{Moisture holding capacity methodology}

Each bedding type was investigated for basic moisture holding capacity under laboratory conditions. Bedding was supplied in its original dried form by the manufacturer. One hundred gram dried mass of each bedding type was weighed (Salter, UK) and placed into a mesh basket measuring $25 \mathrm{~cm}$ by $25 \mathrm{~cm}$ and weighing $350 \mathrm{~g}$ with a collecting tray placed underneath. Equine urine collected non-invasively from one horse with a specific gravity of 1.1 was then syringed into the bedding. The container size was calculated by taking the approximate size of a stable of 3.5 by 3.5 metres and scaling this down to a workable size in the lab of $25 \mathrm{~cm}$ by $25 \mathrm{~cm}$. The same was done with the amount of urine, with an average of 7 litres of urine produced per day scaled down to $466 \mathrm{ml}$. Room temperature throughout the trial was $14 \pm 2.1^{\circ} \mathrm{C}$ and humidity was $47 \pm 5.6 \%$ rh

Moisture holding capacity was calculated on a weight basis by periodically reweighing the basket [wet weight - container weight $(350 \mathrm{~g})$ - weight of bedding (100g)]. This was carried out at 2, 4, 6, 8, 10 and 24 hours post introduction of urine. As it is recommended that urine and faeces be removed from stables at least once a day, no further measures were taken beyond 24 hours. Each trial was repeated three times for each bedding type and a mean weight for each time point calculated. A one way repeated measures ANOVA was used to compare wet weights between each bedding type. 


\section{Results}

\section{Microbial results}

Results from the microbial count after overnight incubation with each bedding type are shown in Table 2. Three of 5 strains tested, E. coli, D. nodosus and $D$. congolensis were not detectable (limit of detection $10^{2} \mathrm{cfu}^{\mathrm{ml}} \mathrm{l}^{-1}$ ) when incubated with Corsican pine, Scots Pine and Sitka Spruce.

There was a significant difference in S. zooepidemicus counts between bedding type as determined by the one-way ANOVA $(F(4,10)=929.1, p<0.001)$. According to the Tukey post-hoc test, all bedding were statistically different from each other except Corsican pine and Scots pine, with straw showing the highest count, and Corsican pine and Scots pine the lowest count for S. zooepidemicus.

There was also significant differences in S. equi counts between bedding type $(F(4,10)=26.2, p<0.001)$. Counts in hemp and straw were significantly higher than in Scots pine and Sitka spruce while Corsican pine showed the lowest count for S. equi. E. coli counts were significantly higher in hemp compared to straw $(F(1,4)=1250.6$, $\mathrm{p}<0.001)$. However there was no significant differences in $D$. nodosus and $D$. congolesis counts between hemp and straw $(p>0.05)$.

Overall, hemp and straw showed the highest colony counts for all bacterial strain tested while Corsican and Scots pine showed the lowest colony counts.

\section{Moisture holding capacity results}

There was a significant difference in moisture holding capacity between all bedding types, $F(3,56)=106.2, p=0.001$ with the pine based bedding absorbing significantly more urine when compared to all other bedding types (figure 1). The 
amount of urine absorbed increased over time up to a period of twenty four hours for the pine and hemp bedding at which point no further measurable absorption took place. The amount of urine absorbed increased over time up to a period of eight hours for the spruce and straw bedding after which no further measurable absorption took place (figure 2).

\section{Discussion}

Pine bedding presented with significantly less bacterial growth for each of the bacteria types tested when compared to other commonly used equine bedding substrates including hemp and straw. Furthermore, wood based bedding of pine and spruce absorbed and retained significantly more urine and continued to do so for up to twenty four hours when compared to the other bedding types tested which absorbed urine for up to eight hours.

With regards to moisture holding capacity, it must be stressed that this trial took place in a laboratory setting. In a horses stable, moisture will be introduced sporadically to the bedding over a longer period each time the horse passes urine. Therefore, the bedding will have a chance to absorb this moisture and dry out before the introduction of further urine. This part of the trial was conducted to gain a basic idea of moisture holding capacity. Results may be different if this trial were to be repeated in field conditions and is an area of future investigation.

Hemp and straw bedding continued to absorb moisture for a total of eight hours. This is still satisfactory in terms of equine hygiene as most horse owners will remove dirty bedding twice per day. Further work must now be carried out in field conditions to ascertain the rate at which moisture is removed by each bedding type and how much 
moisture each bedding type is capable of absorbing. This is important as the amount of free urine in the horses bed could contribute to bacterial growth by providing a source of nitrogen.

The bacteria types tested pose varying levels of disease risk for the equine species ranging from the discomfort of distal limb dermatitis associated with $D$. congolensis to the significant welfare and economic implications of strangles caused by the bacterium S. equi. Recent work on pathogen control strategies in sheep suggest that the environment may assist persistence of footrot caused by $D$. nodosus, one of the bacteria tested during the current study and one which costs the United Kingdom farming industry £24 million per year (Nieuwhof and Bishop, 2005). Footrot occurs in winter in housed sheep therefore $D$. nodosus must also survive on bedding long enough to be transmitted between animals and Green and George (2008) suggest that damp bedding is an ideal medium for survival. As pine bedding produced the least bacterial growth and the largest moisture holding capacity during this study then this suggests pine based bedding to be a suitable choice for housed sheep and indeed for horses to prevent spread of disease and poor foot health. Transmission of the bacteria from one animal to another will always occur via the surface on which they are kept Green and George (2008). It is therefore important that further work be carried out to improve knowledge on bacterial survival and transmission in a range of bedding substrates and surfaces.

It is not clear at this stage for this particular study why pine based bedding produced the least bacterial growth but there are a number of factors to consider. Evidence suggests that equine health improves (foot and respiratory health in particular) when horses are stabled on pine based product and this could be due to the reported pathogen resisting properties of pine (Kim et al., 2005; Zeng et al., 2012). 
Valimaa et al (2007) tested 30 species of hard and soft wood trees for their antimicrobial activity and report that by far the most consistent antibacterial and antifungal properties were associated with extracts of Pinus species. The authors suggest this antimicrobial effect is associated with stilbenes, a polyphenol found in the wood. This compound may be lost in the processing of the bedding or with age of the wood and so other factors that could contribute to the bacterial resistance must be considered.

One factor to consider would be the physical properties of the bedding itself including moisture holding capacity. Animal urine provides a source of nitrogen which assists bacterial growth. If the bedding substrate used can remove and hold urine then this will inhibit the growth of the bacteria. During this study pine based bedding produced the least bacterial growth and was also the most absorbent substrate which supports this theory.

During this study pine and spruce bedding reduced the growth rate of bacteria in a controlled laboratory setting. It is therefore important that these lab findings be tested in field conditions. If the bedding substrate used as part of a horse's management can reduce survival and spread of disease causing pathogens, then this has application in biosecurity measures for the equine industry. Bedding is used not only in the horses own stable but in horse transporters, temporary stables at competitions and equine stabling at veterinary centres all of which are utilised by many different horses and are key areas where disease prevention is paramount. Bedding choice may be one way of reducing disease risk in these scenarios.

As well as identifying and managing disease, prevention of pathogen transmission needs further research. Horse husbandry, in particular choice of bedding substrate, 
can potentially make an important contribution to prevention or reduction of disease outbreak.

\section{Acknowledgement}

The authors wish to thank BEDMAX ${ }^{\mathrm{TM}}$ for providing the bedding materials tested during the study and for part funding of the project in collaboration with Nottingham Trent University. We also wish to thank Samantha York and her stallion Oakring

Chadun for on demand provision of the urine used in the trial.

\section{Conflict of interest}

This project was part funded by BEDMAX ${ }^{\mathrm{TM}}$ who also supplied three of the bedding substrates tested. Nottingham Trent University and the authors of this study have no commercial or personal relationships with this company.

\section{References}

Borhan, M.D., Rahman, S., Hammer, C. (2014) Water absorption capacity of flax and pine horse beddings and gaseous concentrations in bedded stalls. J. of Eq Vet Sci. 34, 611-618.

Colles, C.M., Colles, K. M., Galpin, J.R. (2010) Equine pastern dermatitis. Eq Vet Edu. 22(11), 533-587.

Elfman, L., Riihimaki, M., Pringle, J., Walinder, R. (2009) Influence of horse stable environment on human airways. J. Occu Med and Toxicology. 4, 10, 1-7. 
Green, L.E., George, T.R.N. (2008) Assessment of current knowledge of footrot in sheep with particular reference to Dichelobacter nodosus and implications for elimination or control strategies for sheep in Great Britain. Vet J. 173-180.

Hogan, J.S., Smith, K.L., Todhunter, D.A., Schoenberger, P.S. (1990) Bacterial counts associated with recycled newspaper bedding. J. Dairy. Sci. 73:1756-1761.

Ivens, P.A., Matthews, D., Webb, K., Newton, J.R., Steward, K., Waller, A.S., Robinson, C., Slater, J.D. (2001) Molecularcharacterisation of 'strangles' outbreaks in the UK: the use of M-protein typing of Streptococcus equi spp. Eq Vet J.. 43 (359364).

Kaneps, A. J. (2014) Equine Sports Medicine and Surgery (Second Edition) pp272 Sauders, Elsevier.

Lindahl, S., Soderlund, R., Frosth, S., Pringle, S., baverud, V., Aspan, A. (2011) Tracing outbreaks of Streptococcus equi infection (strangles) in horses using sequence variation in the seM gene and pulsed-field gel electrophoresis. Vet. Microbiol. 153, 144-149.

Liu, R., Mu, L., Liu, H., Wie, L., Yan, T., Chen, M., Zhang, K., Li, J., You, D. (2011) Two antimicrobial and nematicidal peptides derived from sequences encoded Picea sitchensis. J. Peptide Sci. 17(9), 627-31.

Nieuwhof, G.J., Bishop, S.C. (2005) Costs of the major endemic diseases of sheep in Great Britain and the potential benefits of reduction in disease impacts. Anim. Sci, 81, 57-67. 
Pearson, E.G., Leavengood, S., Reeb, J.E. (2000) Comparison of the absorptive capacity of shavings of Western juniper, western redcedar and Douglas Fir for animal bedding. Forest Products J. 50(6), 57-60.

Petrov, K.K., Dicks, L.M.T. (2013) Fusobacterium necrophorum and not Dichelobacter nodosus is associated with equine hoof thrush. Vet. Microbiol. 161, 350-352.

Pilsworth, R.C., Knottenbelt, D. (2007) Skin diseases refresher: Dermatophilosis (rain scald). Eq. Vet. Edu. 19 (4), 212-214.

Rasmussen, C.D., Haugaard, M.M., Petersen, M.R., Nielsen, J.M., Pedersen, H.G., Bojesen, A.M., (2013) Streptococcus equi subsp. zooepidemicus isolates from equine infectious endometritis belong to a distinct genetic group. Vet Res 44, 26.

Rauha, J.P., Remes, S., Heinonen, M., Hopia, A., Kahkonen, M., Kujala, T., Pihlaja, K., Vuorela , Pia Vuorela, H. (2000) Antimicrobial effects of Finnish plant extracts containing flavonoids and other phenolic compounds. Intl. J. Food Microbiol. 56 3-12.

Sarac, Z., Matejic, J.S., Stojanovic-Radic, Z., veselinovic, J.B., Dzamic, A.M>, Bojovic, S., Marin, P.D. (2014) Biological activity of Pinus nigra terpenes- Evaluation of FtsZ inhibition by selected compounds as contribution to their antimicrobial activity. Comps. in Biol and Med. 54, 72-78.

Smith, K.C., Blunden, A.S., Whitwell, K.E., Dunn, K.A., Wales, A.D., (2003) A survey of equine abortion, stillbirth and neonatal death in the UK from 1988 to 1997. Eq. Vet. J., 35, 496-501. 
Tanner, M.K., Swinker, A.M., Beard, M.L., Cosma, G.N., Traub-Dargatz, J.L., Martinez, A.B., Olenchock, S.A. (1997) Effect of phone book paper versus sawdust and straw bedding on the presence of airborne gram-negative bacteria, fungi and endotoxin in horse stalls. Equine Nutrition and Physiology Society annual Symposium. May 28-31, Fort Worth, Texas, USA.

Timoney, J.F., Kumar, P. (2008) Early pathogenesis of equine Streptococcus equi infection (strangles). Eq. Vet. J. 40 (7), 637-642.

Valimaa, A.L., Honkalampi-amalainen, U., pietarinen, S., Willfor, S., Holmbom, B., von Wright, A. (2007) Antimicrobial and cytotoxic knotwood extracts and related pure compounds and their effects on food-associated microorganisms. Intl J. of Food Microbiol. 115, 235-243.

Waller, A.S. (2013) Strangles: Taking steps towards eradication, Vet. Microbiol.167 (2013) 50-60.

Webb, K., Jolley, K.A., Mitchell, Z., Robinson, C., Newton, J.R., Maiden, M.C., Waller, A. (2008) Development of an unambiguous and discriminatory multilocus sequence typing scheme for the Streptococcus zooepidemicus group. Microbiol. 154, 30163024.

Webster, A.J.F., Clarke, A.F., Madelin, T.M., Wathes, C.M. (1987) Air hygiene in stables: Effects of stable design, ventilation and management on the concentration of respirable dusts. Eq. Vet. J. 19 (5), 4480453.

Werhahn, H., Hessel, E.F., Bachhausen, I., Van de Weghe, H.F.A. (2010) Effects of different bedding materials on the behaviour of horses housed in single stalls. J. Eq. Vet. Scie.30 (8), 425-431. 
Wheeler, E., Zajaczkowski, J.S. (2002) Horse facilities: Horse manure stable management. P.S. University, Editor, University park, P.A.

Wood, J.L., Newton, J.R., Chanter, N., Mumford, J.A., (2005) Association between respiratory disease and bacterial and viral infections in British racehorses. Clin. Microbiol. 43, 120-126.

Velineni, S., Breathnach, C.C., Timoney, J.F., (2014) Evidence of lateral gene transfer among strains of Streptococcus zooepidemicus in weanling horses with respiratory disease. Infection, Genetics and Evol. 21, 157-160.

Table 1. Microbial strains used during the study

This tables provides details of the microbial strains used during the study, their collection number, growth media used and incubation requirements.

\begin{tabular}{|c|c|c|c|}
\hline Microbial species & Collection number & Media & $\begin{array}{c}\text { Incubation } \\
\text { requirements }\end{array}$ \\
\hline $\begin{array}{c}\text { Streptococcus } \\
\text { equi }\end{array}$ & NCTC 9682 & Nutrient agar/broth & 24 hours at $37^{\circ} \mathrm{C}$ \\
\hline $\begin{array}{l}\text { Streptococcus } \\
\text { zooepidemicus }\end{array}$ & NCTC 7023 & Nutrient agar/broth & 24 hours at $37^{\circ} \mathrm{C}$ \\
\hline $\begin{array}{c}\text { Fusobacterium } \\
\text { necrophorum }\end{array}$ & ATCC 25286 & $\begin{array}{c}\text { Blood agar base } \\
\text { no. } 2+5 \% \\
\text { defribrinated horse } \\
\text { blood/nutrient broth } \\
\text { Blood aqar base }\end{array}$ & $\begin{array}{c}\text { Anaerobically for } 48 \\
\text { hours at } 37^{\circ} \mathrm{C}\end{array}$ \\
\hline $\begin{array}{c}\text { Dermatophilus } \\
\text { congolensis }\end{array}$ & NCTC 5175 & $\begin{array}{c}\text { no. } 2+5 \% \\
\text { defribrinated horse } \\
\text { blood/nutrient broth }\end{array}$ & 48 hours at $37^{\circ} \mathrm{C}$ \\
\hline $\begin{array}{c}\text { Dicelobacter } \\
\text { nodosus }\end{array}$ & ATCC 25549 & $\begin{array}{l}\text { Tryptone soya agar } \\
+5 \% \text { sheep } \\
\text { blood/cooked meat } \\
\text { broth }+1 \% \text { glucose }\end{array}$ & 5 days \\
\hline
\end{tabular}

This article is protected by copyright. All rights reserved. 
Table 2. Mean \pm SE of Log viable count (cfu. $\mathrm{ml}^{-1} ; \mathrm{n}=3$ ) for each bacterial strain incubated overnight with different bedding type. Mean with different letters differ significantly within column ( $p \leq 0.05)$, LOD: limit of detection.

\begin{tabular}{llllll}
\hline Bedding type & S. zooepidemicus & S. equi & E. coli & D. nodosus & D. congolensis \\
\hline Hemp & $6.45 \pm 0.020^{\mathrm{a}}$ & $5.26 \pm 0.015^{\mathrm{a}}$ & $4.40 \pm 0.026^{\mathrm{a}}$ & $2.434 \pm 0.219$ & $4.83 \pm 0.018$ \\
Straw & $7.13 \pm 0.008^{\mathrm{b}}$ & $4.89 \pm 0.012^{\mathrm{a}, \mathrm{c}}$ & $5.40 \pm 0.010^{\mathrm{b}}$ & $3.021 \pm 0.126$ & $4.73 \pm 0.052$ \\
Corsican pine & $2.85 \pm 0.087^{\mathrm{c}}$ & $3.33 \pm 0.039^{\mathrm{b}}$ & $<$ LOD & $<$ LOD & $<$ LOD \\
Scots pine & $3.04 \pm 0.111^{\mathrm{c}}$ & $4.11 \pm 0.013^{\mathrm{c}}$ & $<\mathrm{LOD}$ & $<\mathrm{LOD}$ & $<$ LOD \\
Sitka spruce & $4.36 \pm 0.011^{\mathrm{a}}$ & $4.25 \pm 0.322^{\mathrm{c}}$ & $<\mathrm{LOD}$ & $<\mathrm{LOD}$ & $<\mathrm{LOD}$ \\
P value & $<0.001$ & $<0.001$ & $<0.001$ & 0.081 & 0.130
\end{tabular}

Figure 1. Mean moisture holding capacity by weight for each of four bedding types tested.

This figure shows the mean moisture holding capacity by weight $(\mathrm{g})( \pm \mathrm{SD})$ of each bedding type of pine, spruce, hemp and straw. Pine bedding held significantly $(p+0.001)$ more moisture when compared to all other bedding types.

Figure 2. Mean $( \pm S D)$ wet weight over time for each of four bedding substrates tested.

This figure shows the mean $( \pm S D)$ wet weight of each bedding type of pine shavings (black), spruce shavings (white), hemp (grey) and straw (hatched) over a twenty four hour period. Bedding was weighed at 2 hours post introduction of urine $(466 \mathrm{mls})$ and then at four hours, six hours, eight hours and twenty four hours post introduction of urine. Each bedding was tested three times and a mean calculated.

This article is protected by copyright. All rights reserved. 

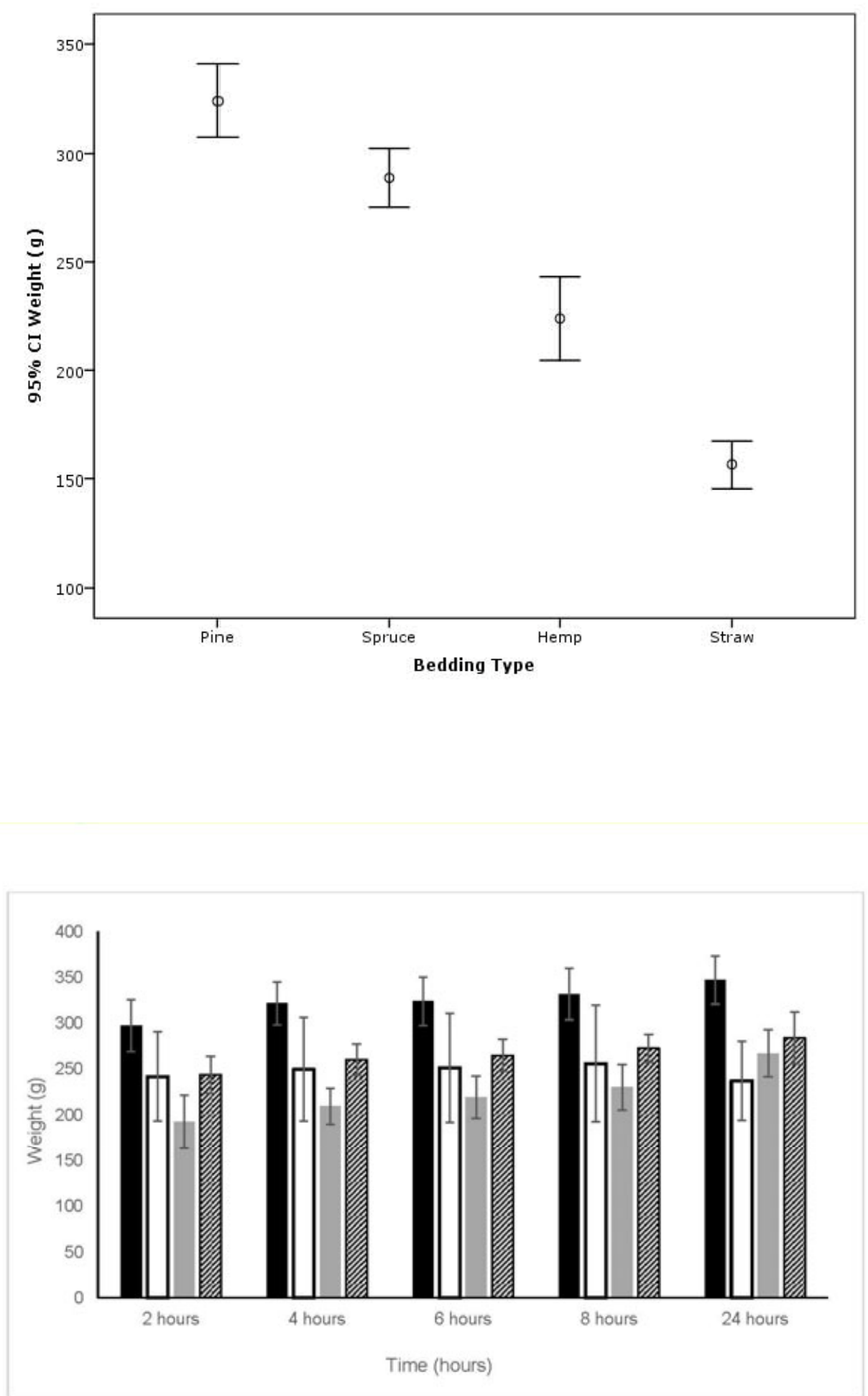

This article is protected by copyright. All rights reserved. 